\title{
An Empirical Analysis of the Pricing of Bank Issued Options versus Options Exchange Options
}

\author{
Jenke ter Horst ${ }^{1}$ and Chris Veld ${ }^{2}$
}

March 1, 2006

JEL codes : G13 and G14

keywords: financial marketing, framing, bank-issued options, long-term call options, call warrants

\footnotetext{
${ }^{1}$ Corresponding author. Jenke ter Horst is an Associate Professor of Finance at the Department of Finance, CentER and Netspar at Tilburg University, P.O.Box 90153, NL-5000 LE Tilburg, the Netherlands. Tel: +31 134668211; fax: +31 134662875; email J.R.terHorst@uvt.nl. Part of the research for this project was done while Jenke ter Horst was visiting the Robert H. Smith Business School (University of Maryland).

${ }^{2}$ Chris Veld is an Associate Professor of Finance in the Faculty of Business Administration at Simon Fraser University; email: cveld@sfu.ca. Part of the research of this project was done while Chris Veld was affiliated with Tilburg University and while he was visiting the Schulich School of Business (York University).
} 


\begin{abstract}
Since 1998, large investment banks have become active as issuers of options, generally referred to as call warrants or bank-issued options. This has led to an interesting situation in the Netherlands, where simultaneously call warrants are traded on the stock exchange, and long-term call options are traded on the options exchange. Both entitle their holders to buy shares of common stock. We start with a direct comparison between call warrants and call options, written on the same stock and with the same exercise price, but where the call option has a longer time to maturity. In 13 out of 16 cases we find that the call warrants are priced higher, which is a clear violation of basic option pricing rules. In the second part of the analysis we use option pricing models to compare the pricing of call warrants and call options. If implied standard deviations from options are used to price the call warrants, we find that the call warrants are strongly overpriced during the first five trading days. The average overpricing is between 25 and 30 percent. Only a small part of the overpricing can be explained by rational arguments such as transaction costs. We suggest that the overvaluation can be explained by a combination of an active financial marketing by the banks and the framing effect.
\end{abstract}




\section{Introduction}

The end of the 1990s has shown a remarkable development in the international option markets. Until then the issuance of options was mostly organized by official options exchanges. From 1998 banks became very active as options issuers. This phenomenon was not entirely new. Around 1990 American and Canadian banks were very active issuers of Nikkei put warrants ${ }^{1}$. In the beginning of the 1990s, Dutch banks also actively issued options on several European indexes. These were indexes on which no options exchange options were avail$a_{b l e}^{2}$. The large scale in which banks started to issue options at the end of the 1990s was especially remarkable. For example, in October 2001 no less than 830 call warrants were outstanding on Euronext Brussels, 1,047 call warrants were outstanding on Euronext Amsterdam, and even 4,952 on Euronext Paris ${ }^{3,4}$. Furthermore, it was noteworthy that this trend could be witnessed in Europe, Asia, and Australia, but not in North America ${ }^{5}$.

Bank-issued options are generally issued under the name "call warrants". It should be noticed that call warrants are different from the securities that are traditionally referred to as warrants. The term warrant traditionally refers to a right issued by a company to buy a certain number of new shares in this company during a specific period (the exercise period) at a specific price (the exercise price $)^{6}$. Here lies an important difference with call warrants, since call warrants are generally issued by large international investment banks. Consequently, call warrants entitle the holder to buy existing shares rather than new shares. In the remainder of this paper we will refer to the bank-issued options either by the term "call warrant", or simply "warrant". The securities that are traditionally referred to as warrants will, from now on, be referred to as "traditional warrants".

The fact that warrants and call options are outstanding, which in many cases entitle their holders to buy the same common stocks, automatically leads to the question whether they carry the same prices. This is especially the case since the differences between call warrants and call options are marginal. The most important differences are the fact that the number of contracts is fixed in case of call warrants, that the credit risk for call warrants is not borne by the clearing house of the options exchange, and that it is not possible for other parties to go short in call warrants. Given the fact that these two financial instruments are almost identical, they should carry the same prices. We test whether this is really the case. As far as there are price deviations, we also try to find a possible explanation.

We start by examining whether it is possible to draw conclusions from a direct comparison of prices of call warrants and call options. Our sample con- 
tains 16 cases where call warrants and call options, written on the same stock, have the same exercise price, but where the call options have a longer time to maturity than the call warrants. Since the call warrants and the call options are both of the American type, simple option pricing rules state that the call options should have the same or a higher price than the call warrants. The reason for this is that most of the variables that determine the value of these securities are the same (exercise price, underlying stock price, volatility, dividend yield, risk-free interest rate), but that the option can be exercised for a longer period than the call warrant. Contrary to our a priori expectations, we find that in 13 out of the 16 cases the warrants carry a higher price during most of the research period that comprises the first five trading days. This gives a first indication that the warrants are overpriced compared to the options. Unfortunately, such a direct comparison is not possible for our whole sample. In most cases the warrants do not only have different maturities from the call options, but also different exercise prices. Therefore, we also use option pricing models to test for the price differences. More precisely, we use implied standard deviations from long-term options to price the warrants. We find that during the first five trading days, the call warrants are, on average, overpriced by approximately 30 percent. This result holds for all three models that we test, i.e. the model of Black and Scholes (1973), and the Square Root version of the Constant Elasticity of Variance model of Cox and Ross (1976), both corrected for continuous dividend payments, and the Binomial model of Cox et al. (1979) with discrete dividend payments. Furthermore, we find that $99 \%$ of the warrants are overvalued.

It is not possible to arbitrage the overvaluation away, since it is not possible to short the warrants ${ }^{7}$. However, it still remains remarkable that investors are willing to pay much more for call warrants than for almost identical call options. We find that institutional differences, such as transaction costs, at most only explain a small part of the overpricing. We suggest that the overpricing is caused by a combination of an active financial marketing by the banks and framing, as first outlined by Shefrin and Statman (1993). Banks have created a special image for call warrants through an active marketing. They managed to frame warrants in such a way that they look like a completely different financial instrument than call options. In this sense our findings are similar to those of Cooper et al. (2001). In the period before the bursting of the Internet bubble, they find a strongly positive stock market reaction to the announcement of corporate name changes to Internet-related dotcom names. We conclude that name changes may be important, and, as our study suggests, investors may be attracted to the name "warrant".

The remainder of the paper is organized as follows. In Section 2 we shortly 
discuss the development of the market for call warrants. In Section 3 we describe the data-set, the results of the direct comparison of call option and call warrant prices, and the methodology for the comparison using option pricing models. Section 4 contains the results for this comparison. In Section 5 we discuss to which extent our results can be explained from the institutional differences between options and warrants. Section 6 contains the results from our discussions with practitioners and from our searching the practical literature and the financial press. The paper concludes with Section 7 in which the summary and conclusions are presented.

\section{Institutional Setting}

The history of call warrants in the Netherlands started in 1986 with the issuance of so-called FALCONS Royal Dutch by Robeco ${ }^{8}$. After this first issue they were issued under a number of different names in the Netherlands, such as covered warrants and EAGLES ${ }^{9}$. In the period of 1986 until 1997 only 32 call warrants were issued in the Netherlands ${ }^{10}$. The issuance of call warrants really took off in June 1998 with the issuance of a number of call warrants by the German Commerzbank. The call warrants issued since then have different underlying values. These include large Dutch stocks, large foreign stocks (e.g., Nokia and Amazon.com), national and international indexes (e.g., the DAX index and the Nikkei index), and baskets of stocks. The market for call warrants in the Netherlands is strongly dominated by a few large banks. For example, according to the official newspaper of Euronext Amsterdam, De Officiële Prijscourant van de Effectenbeurs, on November 13, 2001 in total 877 call warrants were outstanding. Of these call warrants, $94(11 \%)$ were issued by the Dutch ABN Amro Bank, 85 (10\%) were issued by the American Citibank, 291 (33\%) were issued by the German Commerzbank, and 361 (44\%) were issued by the French

Société Générale Acceptance. The remaining 46 (5\%) call warrants were issued by a number of smaller parties, mainly other Dutch banks. This underlines the international character of the market for call warrants.

Despite the large extent of the market for call warrants, there is hardly any empirical research available on the pricing of these securities. Veld and Verboven (1995) compare the prices of Dutch equity warrants and long-term call options. They find that the equity warrants are systematically overpriced compared to the long-term call options. However, the equity warrants in their comparison are mostly traditional equity warrants. Only one of the warrants in their sample was a call warrant as described above. Chan and Pinder (2000) compare the 
pricing of call warrants and call options on the Australian market. They find that, on average, warrants are 1.30 to $5.02 \%$ overpriced to electronically traded options and that, on average, they are 7.50 to $10.63 \%$ overpriced compared to floor-traded options. From their empirical analysis they conclude that the overpricing of warrants compared to options can be explained by the liquidity premium in the warrant market. Bartram and Fehle (2004) compare prices of call options, traded on the German Eurex market, and call warrants, traded on the German Euwax market. They find that the warrant ask prices are $4.7 \%$ higher than the option ask prices, and that the warrant bid prices are $9.9 \%$ higher than the option bid prices. They explain this result from a difference in trading clienteles that differ with respect to the probability of selling the option back to the dealer/issuer before maturity.

\section{Data description and methodology}

\subsection{Data description}

We analyze the prices of call warrants that were issued on Euronext Amsterdam in the period from January 1, 1999 to December 31, 2001. Call warrants are identified from the Dutch financial newspaper, De Officiële Prijscourant van de Effectenbeurs, an official publication of, the stock and options exchanges in Amsterdam. Information on the warrants expiration date, exercise price and the warrant-ratio (this is the number of warrants that are needed to buy one share of common stock) is all derived from Datastream. The warrants are issued by trade. Therefore, there is no explicit issue price for the warrants. The banks generally publish indicative issue prices; however, these do not bind them. The actual issue price is the first trading price of the warrants. Warrants are only included if, during the first 10 trading days, at least five days can be found on which at least an option with a longer maturity and an option with a shorter maturity are traded, i.e. have a positive trading volume. The first five trading days in which an option is available are taken into account. Note that a trading day is defined as a day on which Datastream reports a positive trading volume for the warrant. We restrict ourselves to the analysis of call warrants on individual companies for which there are also long-term call options outstanding on the options exchange in Amsterdam. In the period from January 1, 1999 to December 31, 2001, we identify a total of 275 call warrants for which there are also long-term call options outstanding. Price data are taken from Datastream. With regard to 35 call warrants, no information is available in Datastream. Therefore these warrants are eliminated from our sample. The information on the warrant conditions is also derived from Datastream. This information 
is verified using the original issuance prospectuses of the call warrants. The latter are available on the website of Euronext Amsterdam (www.aex.nl) and on the websites of the issuing banks. In five cases we find conflicting information between Datastream and the issuance prospectuses. Since it is not possible to retrieve the correct information at the issuance dates, we eliminate these five observations. This leaves us with 235 observations.

\subsection{Results from a direct comparison}

We first examine whether it is possible to draw conclusions from a direct comparison of prices of call warrants and call options that are written on the same stock. Our sample of 235 observations contains 16 cases where call warrants and call options have the same exercise price, but where the options have a longer maturity than the warrants. According to standard option pricing theory, these options should at least have the same price as the warrants ${ }^{11}$. The reason for this is that the options give their holders the same rights as the warrants, but they can be exercised during a longer time period. We find a violation of this basic option pricing rule in no less than 13 out of the 16 cases. In all these cases the call warrants are more expensive than the call options during most of the first 5 trading days.

Consider for example the call warrants issued by Commerzbank on the stock of Ahold. The call warrants are issued on August 18, 2000, the exercise date is August 2, 2002, and the exercise price is $€ 37$. The warrant ratio is 0.10 , which means that 10 call warrants are necessary to buy one share of common stock. The call warrants were first traded on August 24, 2000, for a price of $€ 0.42$ per warrant. This means that the price for a right to buy one share of Ahold is $€ 4.20$. This price can be compared to the price of a long term call option on Ahold, traded on the same day, with the same exercise price and with a maturity until October 18, 2002. Although basic option pricing rules would predict that the call options would have a higher price than the call warrants, we find that these call options are only traded at a price of $€ 3.45$. Figure 1 includes a comparison of the prices of these call warrants and call options during the first 5 trading days.

\section{[Please insert Figure 1 here]}

In this figure it can be seen that, during the first 5 trading days, the warrants are priced higher every day. This is remarkable, given that the option gives the same rights as the warrants, but for a longer maturity. Unfortunately, a direct comparison such as this one is not always possible. The reason for this is that in 
most cases, the warrants do not only have different maturities but also different exercise prices. Therefore we continue our analysis using option pricing models.

\subsection{Methodology}

The methodology in the remainder of this paper consists of the comparison of model and market prices on the issuance date, and the immediate period thereafter, of the call warrants. Previous empirical research on the pricing of traditional warrants generally concludes that the model of Black and Scholes (1973) and the Square Root model of Cox and Ross (1976), both corrected for dividend payments, are the most suitable models for the pricing of traditional

warrants $^{12}$. Both call warrants and traditional warrants are in fact long-term call options. For that reason it is likely that the models that are suitable for the pricing of traditional warrants are also most fit for the pricing of call warrants ${ }^{13}$.

Both the Black and Scholes option pricing model and the Square Root model are special cases of the Constant Elasticity of Variance model (CEV-model). In the CEV-model, the price of the underlying common stock is assumed to follow a constant elasticity of variance process, which has the form:

$$
d S / S=\mu d t+\delta S^{(\Psi-2) / 2} d Z,
$$

where:

$\mathrm{S}=$ price of the underlying stock;

$\mu=$ expected rate of return on the stock;

$\Psi=$ elasticity factor;

$\mathrm{Z}=$ Wiener process.

The instantaneous standard deviation of the percentage return (or volatility), $\sigma$, is given by the equation:

$$
\sigma=\delta S^{(\Psi-2) / 2}
$$

When $\Psi$ equals 2 , the volatility is a constant, $\delta$, and the stochastic process generating returns is a lognormal diffusion process, the process assumed in the Black and Scholes (1973) option-pricing model.

Cox and Ross (1976) drop the assumption of a constant volatility and, instead, focus their attention on the case that: $0 \leq \Psi<2$. In this case the volatility decreases as the stock price increases. This inverse relationship can especially be explained by financial leverage arguments. As the stock price falls, 
the market value of the firm's debt will also fall because of an increased perception of bankruptcy. The decrease in the market value of equity will be larger than the decrease in the market value of debt, which produces a rise in the firm's debt-to-equity ratio. This increase in financial leverage causes an increase in the risk of the equity, which leads to a rise in the stock's volatility. According to Beckers (1980), a similar effect can be observed if the firm has almost no debt. Since every firm faces fixed costs, which have to be met irrespective of its income, a decrease in income will decrease the value of the firm and at the same time increase its riskiness.

As a special case of the general CEV-model, Cox and Ross (1976) present the Square Root model. This model has a parameter value $\Psi$ of 1 . The formula for the Square Root model can be derived by substituting the value 1 for the factor $\Psi$ in the general equation of the CEV-model. This model is called the Square Root model because it assumes that the volatility is inversely related to the square root of the stock value.

As mentioned above, we use both the models of Black and Scholes (1973) and the Square Root model of Cox and Ross (1976) for the calculation of call warrant model prices. Given the long maturity of the call warrants we use dividend corrected versions of both models. Dividends are assumed to be paid continuously as first derived by Merton (1973). When we refer to the model of Black and Scholes (1973) or the Square Root model of Cox and Ross (1976) in the remainder of this paper, we mean the versions of these models that are corrected for continuous dividend payments. Both the call warrants and the call options are American. This means that they can be exercised from the issuance date until the expiration date. Merton (1973) has shown that it can be rational to exercise an American call option (warrant) before an ex-dividend date. This effect is not incorporated in the model of Black and Scholes (1973)

and the Square Root model. For this reason we also use the Binomial model of Cox et al. (1979). In the limit case this model converges into the model of Black and Scholes (1973). The advantage of the Binomial model is that it allows the incorporation of discrete dividend payments, thus allowing for the possibility of early exercise.

\subsection{Estimation of the variables}

All three models require six variables. The first four variables are the same for all three models, i.e. (1) the price of the underlying stock (S); (2) the exercise price $(\mathrm{X})$; $(3)$ the remaining time to maturity $(\mathrm{T})$, and (4) the riskfree interest rate (r). Variables (1), (2) and (3) can be observed directly. The fourth variable, the risk-free interest rate, can be approximated as the average 
yield on a government bond with the same maturity as the call warrant. Since all call warrants have a maturity that is around 2 years, we estimate the riskfree interest rate as the average yield on government bonds with a maturity of 2 years ${ }^{14}$. In addition, the model of Black and Scholes (1973) and the Square Root model require the dividend yield. This is also available from Datastream. The Binomial model requires the discrete dividend payment (D) that will be paid during its remaining maturity. We estimate the discrete dividend as the last dividend payment before the first trading date. This discrete dividend is also obtained from Datastream ${ }^{15}$. The final variable that has to be estimated for all three models is the standard deviation of the returns on the underlying stocks, commonly referred to as the volatility. We use the implied standard deviations of long-term call options that are traded on the same stocks in order to estimate this variable. There is a problem here, in that usually the maturity and the exercise price of the call warrants are different from the maturity and the exercise price of the long-term call options. This causes a problem because the volatility is different between maturities. Brenner and Subrahmanyam (1988) refer to this phenomenon as the "term structure of volatility". Besides that, Hull (2006, page 379-381) notes that volatilities for equity options are different between exercise prices. In general, the volatility decreases as the exercise price increases. The volatility used to price a low-exercise price option is significantly higher than that used to price a high-exercise price option ${ }^{16}$. In order to calculate a useful volatility, we use a "volatility surface" in the spirit of Hull (2006, page 381383). To be more specific, the following equations are used in order to arrive at a weighted implied volatility of the different options:

$$
\begin{gathered}
\text { shortvol }=\frac{|X 1-X|}{|X 2-X 1|} * i m p 2+\frac{|X 2-X|}{|X 2-X 1|} * i m p 1 \\
\text { longvol }=\frac{|X 3-X|}{|X 4-X 3|} * i m p 4+\frac{|X 4-X|}{|X 4-X 3|} * i m p 3 \\
\text { whtimp }=\frac{|T 1-T|}{|T 3-T 1|} * \text { longvol }+\frac{|T 3-T|}{|T 3-T 1|} * \text { shortvol }
\end{gathered}
$$

where $i m p 1$ and $i m p 2$ denote the implied volatilities of two call options with a maturity shorter than the warrant, and imp3 and imp4 denote the implied volatilities of two call options with a maturity longer than the warrant, $X 1 \ldots X 4$ are the exercise prices of the respective options, and $T 1 \ldots T 4$ are the maturities of the respective options, $X$ is the exercise price of the warrant, $T$ is the maturity of the warrant, shortvol represents the calculation of the implied volatility of the short-term options and longvol represents the calculation of the implied volatility of the long-term options, and wghtimp represents the calculation of the weighted implied volatility of the two series. Note that warrants are only 
priced if we at least observe one call option with maturity shorter than the warrant, and one call option with a longer maturity. All of the above mentioned variables are acquired from Datastream.

\subsection{Sample selection}

The selection of the final sample is presented in Table 1.

[Please insert Table 1 here]

The research is restricted to call warrants that were issued in the period from January 1, 1999, to December 31, 2001. Only warrants on underlying shares on which also long term call options are available are taken into account. In total, 275 call warrants fulfill this condition. As indicated in Section 3.1, we eliminate 35 observations for which no information is available in Datastream, as well as 5 observations for which there is conflicting issuance information. A problem that may occur is that the option, warrant, and stock markets are not synchronous on the first trading day of the warrant. In other words, the last trade of the warrant, the option, and the stock will probably occur at different times. In order to minimize this problem, we average the difference between the market and model prices of each warrant for the first five trading days. A trading day is defined as a day on which the trading volume of the warrant is positive. As mentioned in Section 3.1, trading days are only taken into account if at least one call option with a longer maturity and one call option with a shorter maturity than the warrant are traded, i.e. have a positive trading volume. This leads to the elimination of 28 observations. Warrants are only included if, during the first 10 trading days, at least five days can be found on which the earlier mentioned two options are traded. This leads to the elimination of 96 observations. The final sample consists of 111 observations. It should be noted that four underlying stocks are not included at all in the final sample. This is mostly caused by the fact that there is not enough liquidity in the options. Therefore there is not enough warrant trading days on which options are also being traded.

\subsection{Summary statistics}

The summary statistics of our sample are presented in Table 2.

[Please insert Table 2 here]

In Table 2 the summary statistics are presented for the different issuers. All call warrants in our sample are issued by either the Dutch ABN Amro bank or by one of the following foreign issuers: Citibank, Commerzbank and Société 
Générale Acceptance. ABN Amro bank is referred to as issuer A. The foreign issuers are indicated as B to D. The average warrant price in Panel A, based on a warrant-ratio of 0.1 , is 0.55 . The average maturity of the call warrants is close to 2 years (1.71 years). The average warrant-ratio is 0.13 . On the trading days, the warrants are actively traded, with an average trading volume of 7,518 warrants and a median of 4,000 warrants. In Panel B, the summary statistics are presented for the warrants that are priced with four options ${ }^{17}$. The results in Panel B are largely the same as in Panel A.

\section{Results}

The overvaluation of each warrant is calculated as:

$$
\text { Overvaluation }=\frac{(\text { market price }- \text { model price })}{\text { model price }} * 100 \%
$$

If the outcome of this calculation is smaller than 0 , there is of course no overvaluation, but an undervaluation instead.

The overvaluation is first calculated for the Square Root model of Cox and Ross (1976). As mentioned before, this model is corrected for continuous dividend payments according to the method presented by Merton (1973). The overvaluation per share is presented in Table 3 .

[Please insert Table 3 here]

In Panel A the overvaluation is presented for the whole sample. From this panel it can be concluded that on average warrants are overvalued by more than $38 \%$. The average overvaluation is significantly different from zero at the $1 \%$ level. It has to be noticed that the overvaluation is not only statistically but also economically significant. The pricing of the call warrants is not based on some historical estimate for the volatility, but is based on the implied volatility of long-term call options that have similar exercise prices and maturities as the call warrants. In this context an overpricing of more than $38 \%$ is very remarkable. If we look at the individual underlying stocks, we see that the overpricing is significantly different from zero at the $1 \%$-level for all stocks for which at least four observations are available. The median overvaluation from Panel A is almost 30\%. This is also significantly different from zero at the $1 \%$ level $^{18}$. In total, 110 out of 111 warrants $(99 \%)$ are overvalued. The total range runs from an undervaluation of $0.6 \%$ to an overvaluation of $153 \%$. The results in Panel A are partly driven by some large outliers. Some of these may be caused by the use of less than four options for the pricing of the call warrants. In such cases, the possibility exists that the warrants are priced using implied standard 
deviations from options that have much higher or much lower exercise prices. For this reason we present separate results for the warrants that are priced with four options. These results are included in Panel B. The average overvaluation in Panel B is somewhat lower, but is still almost 30\% (29.92\%). The median overvaluation slightly drops to $27.55 \%$. The average and the median are both significantly different from zero at the $1 \%$-level. A potential problem with the analysis in Table 3 is that the sample comprises 111 observations of call warrants on 15 firms. If there is a firm-effect, the observations are not independent. In order to test for this we have calculated results for each separate company. These overpricing results can then be considered independently from each other, and we calculate the average of the 15 observations. In addition, the standard deviation of this average is calculated and is reported in the final row of Panel A and B of Table 3. Using this standard deviation we can conclude that the average is still significantly different from zero. In other words, our results are not driven by a firm-effect.

As a further robustness check we have also calculated results for the model of Black and Scholes (1973), corrected for continuous dividend payments. In order to make sure that our results are not driven by the use of a continuous dividend yield, rather than a discrete dividend payment, we have also calculated the overpricing for the Binomial model of Cox et al. (1979). In these calculations we include discrete dividend payments in the model. The average overvaluation for the model of Black and Scholes (1973) is $31.35 \%$. The median overvaluation for this model is $25.55 \%$. The average and the median are both significantly different from zero at the $1 \%$-level. The average overvaluation for the Binomial model is $29.56 \%$ with a median of $25.82 \%^{19}$. Again, the mean and median are significantly different from zero at the $1 \%$-level. Just like the Square Root model, we have also calculated results for these models for the sub-sample of warrants that are priced with four options. The average overvaluation of the sub-sample for the model of Black and Scholes becomes 29.71\%. For the Binomial model, the average overvaluation drops to $27.88 \%{ }^{20}$.

We have also investigated whether the overpricing of the warrants resembles the pattern that can be observed at Initial Public Offerings (IPOs). In the period directly after an IPO, security prices are inflated, which is followed by a long-run underperformance ${ }^{21}$. We investigate this by studying the overpricing of the warrants through time. This analysis is included in Figure 2.

[Please insert Figure 2 here]

This figure presents the average overpricing of call warrants during their maturity. The graph only includes information on warrants that are actually traded on a certain day. For example, the information on day 50 includes the 
average overpricing of all call warrants that were traded, i.e. for which there was a positive trading volume, on the 50th day after their issuance. Call warrants are only taken into account if they fulfill all four of the following conditions:

1. The trading volume of the warrant is positive.

2. There are at least two call options on the same underlying stock that have a positive trading volume: one with a longer maturity and one with a shorter maturity.

3. The overpricing is not more than $150 \%$.

4. The price of the call warrant is at least 0.10 euro.

The third condition is included in order to avoid large outliers to determine the outcome. The reason that we included the fourth condition is that we observed a number of warrant market prices of about 0.10 euro, or sometimes even smaller, with an overpricing of more than $200 \%$. Including these observations would lead to a larger overpricing, which would be based on very small warrant investments. In order to get a more realistic idea of the overpricing, we delete these observations.

The overpricing of the first five days in this graph appears to be smaller than the average overpricing on the first five trading days that we find for the Square Root model (38.25\%). The reason for this is that in the previous calculations we take the first five trading days for each warrant. In some cases the fifth trading day only occurs 20 days or more after the issue. This explains the difference between the results in Figure 2 and the earlier reported results.

Figure 2 shows that the average overpricing remains high until at least one year after the issue. From approximately 450 days the graph shows a downward trend. However, it should be noticed that the results after one year should be treated with caution, since the observations in the graph are often based on a few call warrants. Our results are comparable to the results of Wilkens et al. (2003) who study German reverse convertibles and discount certificates. They also find that these instruments are overpriced directly after the issuance date. However, in their study the overpricing also disappears in time. For reverse convertibles, the overpricing disappears at the end of the maturity, while for discount certificates it disappears after $2 / 3$ of the product's life times ${ }^{22}$.

The disappearance of the overpricing in time somewhat resembles the pattern of the IPOs. However, two important comments are in order. First, the life span of a warrant is limited, whereas the life of a share of common stock is not. At the end of its maturity the value of the warrant is $\operatorname{Max}[0, \mathrm{~S}-\mathrm{X}]$. Therefore, the overpricing should by definition disappear during the warrant's maturity. 
Second, during the first five trading days, the bank will practically only serve as a seller of warrants. After that period, there will likely be cases where the warrant holders may want to dispose of their warrants. Given that the banks all maintain markets in their own warrants; they are likely to be buyers in many cases. Since they are the experts in the pricing of the warrants, the banks are not likely to overpay. This probably also explains the upward peaks around the 500th day after the issuance.

\section{Institutional differences between call warrants and call options}

\section{$5.1 \quad$ Introduction}

In order to explain the differences in prices between call warrants and call options, we investigate the institutional differences between the instruments. We first look at whether the overpricing is different between different issuers. Subsequently, we study the possible impact of transaction cost differences between call warrants and call options. Attention is also paid to the slightly higher flexibility that call warrants offer compared to call options. This is followed by a discussion of the secondary market characteristics for both instruments. Finally, we discuss the lack of arbitrage possibilities.

\subsection{Differences in overpricing between issuers}

We expected a priori, that the prices of the foreign issuers would be higher than that of the Dutch issuers, because the foreign parties have to bear more costs to operate on the Dutch market. This hypothesis is tested in Table 4 where we perform a regression analysis of the overpricing on each of the three foreign issuers.

[Please insert Table 4 here]

The regression analysis in Table 4 is carried out for the overpricing for the Black-Scholes, the Square Root, and the Binomial model. Besides that, we perform the regression analysis for both the complete samples and the subsample of warrant prices that are calculated with all four options. Given that the results of this and the following regressions are virtually the same for all three models, we only present the results for the Square Root model ${ }^{23}$. For both the complete sample and the sub-sample, we find that the warrants from issuer $\mathrm{C}$ are significantly more overpriced than the warrants of the Dutch issuer. For 
issuers B and D we also find the expected significant coefficient. However, the coefficients for both issuers are only significant in the regression for the complete sample. The significance disappears in the regression for the sub-sample.

A priori we also expected that the overpricing would be negatively correlated to the warrant trading volume, the idea being that a larger batch would be sold for a lower price. However, the regression analysis in both panels shows that the reverse relationship is true. The log of the trading volume is positively related to the overpricing, indicating that a higher trading volume is associated with a higher overpricing. The relationship is significant for the whole sample, but not for the sub-sample. Besides the single regressions, we have also run multiple regressions for all variables together. The results of the multiple regressions are mostly similar to those of the single regressions. An interesting exception occurs for the warrant ratio: the multiple regression does not show a significant sign for this factor in both the whole sample and the sub-sample.

\subsection{Transaction costs}

According to the Dutch financial newspaper, Het Financieele Dagblad, of January 24, 2002, more than $70 \%$ of the warrant buyers consist of individual investors. For this reason, it may be interesting to look at the differences in transaction costs between call warrants and call options. It is not possible to make a direct comparison of the transaction costs. The reason for this is that they are charged differently for both financial instruments. Transaction costs for call options are charged per contract. Each contract allows its holder to buy 100 shares of common stock. Transaction costs for warrants are charged in the same way as for shares. That is, a (small) fixed amount is charged as well as a percentage of the market value of the order (in Euros). This means that for call warrants there is no direct relationship with the number of shares that can be bought. Both for call warrants and for call options, different amounts apply between orders placed by phone and Internet orders.

The independent Dutch Internet company "Belegger.nl", compares transaction costs for a number of large Dutch banks and brokers. Based on the information supplied on their web page (per February 19, 2002), we compare transaction costs between call warrants and call options. The results for this comparison are included in Table 5.

[Please insert Table 5 here]

The minimum order for which transaction costs for shares and warrants are presented on this web page is 1,000 . This is the basis for our comparison. In Table 5 we compare transaction costs for four different scenarios. In all scenarios 
we consider call warrants with a warrant ratio of 0.1 . That is, 10 call warrants are needed to buy one share of common stock. We consider four cases: in the first case the warrant price is 0.1 Euro; in the second case it is 0.20 Euro; in the third case it is 0.5 Euro; and in the fourth case it is 1 Euro. The results of the four scenarios are presented on rows 1 to 4 of Table 5. In all cases we present the average of the transaction costs that are presented on this website for the eight banks and/or brokers ${ }^{24}$.

In the first row we assume that the warrant price is 0.1 Euro. The order size of 1,000 Euros would allow the warrant investor to buy 10,000 warrants. If she would like to take a similar position using options, she would have to buy 10 option contracts. In that case, 1,000 shares can also be bought by exercising the option (10 contracts of 100 shares each). The transaction costs for the warrants are presented in columns (2) and (3) of Table 5. The average warrant transaction costs are 15.6 Euro for phone trade and 12 Euro for Internet trade. The average transaction costs for buying 10 option contracts are 52.6 Euro for phone trade (see column (4)), and 42.8 Euro for Internet trade (see column (5)). With regard to these transaction costs, it has to be noticed that the actual difference in most cases has to be doubled. Investors first have to buy the warrants or the options, and if things go well they have to exercise or sell them. In columns (6) and (7), we present the difference of the transaction costs of the call warrants and the call options as a percentage of the warrant price. From Table 5 it can be concluded that the average difference for the phone trade is 37 Euro (52.6 minus 15.6 Euro). If this amount is expressed in the price per warrant it is 0.37 Eurocents per warrant. For a round-trip (buy and sell) the amount is doubled and it is 0.0074 Euro $(=0.74$ Eurocents $)$ per call warrant. In columns (8) and (9) we present the transaction costs as a percentage of the warrant price. In the first row the difference of 0.0074 Euro is divided by the warrant price of 0.10 Euro, resulting in a percentage difference of $7.4 \%$. Based on this case it could be concluded that the difference in transaction costs between warrants and options is substantial. However, three remarks are in order. First, it has to be remarked that the difference for Internet trade is only $6.2 \%$ per call warrant. Second, it can be noticed that the scenario in the first row is the most extreme scenario. Third, even the most extreme transaction cost difference is much smaller than the price difference. Given an average price difference between 25 and 30 percent, the price difference expressed in the price per warrant is between 2.5 and 3 Eurocents.

In the second scenario, we assume that the warrant price is 0.20 Euro. The warrant holder needs 10 warrants to buy one share. Assuming an order size of 1,000 Euro, the investor would buy 5,000 warrants. A similar position can be acquired by buying 5 option contracts. In that case, 500 shares can also be 
bought by exercising the option. The transaction costs for the warrants on the second row are the same as on the first row. The reason for this is that the order size, which determines the transaction costs, is the same. The transaction costs for the options decline, since fewer contracts have to be bought (see columns (4) and (5)). The difference in transaction costs per warrant (for a round-trip), and as a percentage per warrant, are presented in columns (6)-(7), and (8)-(9) respectively. The most important conclusion is the difference in transaction costs, expressed in the price per warrant, declines from $7.4 \%$ to $2.5 \%$ for phone trade, and from $6.2 \%$ to $2.1 \%$ for Internet trade. It is clear that the difference in transaction costs is much smaller if more realistic warrant prices are considered.

In the third scenario, we assume that the warrant price is 0.50 Euro. The warrant holder needs two warrants to buy one share. Assuming an order size of 1,000 Euro, the investor would buy 2,000 warrants. A similar position can be acquired by buying 2 option contracts. The transaction costs for the warrants remain unchanged. From columns (8) and (9) of the third scenario it can be concluded that in this case the difference in transaction costs is negligible. The same conclusion can be reached from the fourth scenario.

Although not reported in this paper, we have also investigated the transaction costs for larger order sizes in order to see whether the difference in transaction costs diminishes for larger order sizes. We find that this is not the case. The difference in transaction costs remains virtually the same ${ }^{25,26}$.

Even though transaction costs cannot explain the full overpricing of the call warrants, it is still possible that they explain a part of the overpricing. From Table 5 it appears that if warrants become more expensive, the difference in transaction costs diminishes. If transaction costs explain part of the overpricing, then we would expect to find a higher overpricing for cheaper warrants. Therefore, we should find a negative relationship between the normalized warrant price and the overpricing. This hypothesis is tested in Table 4. In this table we regress the overpricing on the normalized warrant price. We do indeed find a significantly negative relationship between overvaluation and the normalized warrant price. The significantly negative relationship is found for the whole sample and the sub-sample. However, if the multiple regressions are considered, we only see a significance at the 10\%-level for the whole sample. If the multiple regression for the sub-sample is considered, we do not see any significance anymore for the normalized warrant price. An alternative way to test this hypothesis is by regressing the overvaluation on the moneyness (defined as the ratio of the stock price and the exercise price). The hypothesis is that a higher moneyness is associated with a lower overvaluation. This relationship is confirmed in both the single and the multiple regressions for both the whole sample and the sub-sample. 
An interesting question is for how many call warrants, the difference in transaction costs plays a role at all. As discussed above, the difference in transaction costs is either negligible or lower for the call warrants that have a trading price of 0.5 Euro or higher. In Table 2 we have seen that this is also the average warrant price. We have divided our sample of 111 observations in warrants with an average price lower than 0.15 Euro, warrants with an average price between 0.15 and 0.50 Euro, and warrants with an average price of higher than 0.50 Euro. The difference in transaction costs is relevant for the first group (smaller than 0.15 Euro), somewhat relevant for the second group (between 0.15 and 0.50 Euro), and not at all for the third group (higher than 0.50 Euro). We find that there are only 7 warrants in group 1, 50 in group 2 and 54 in group 3. The average overpricing of the warrants in the third group is $25.21 \%$ for the full sample (with a standard deviation of 3.43 ) and $26.28 \%$ for the sub-sample (with a standard deviation of 5.02) in which the warrant price is based on the prices of 4 options.

\subsection{Flexibility}

Another advantage of warrants for individual investors is that it is easier to start trading warrants than it is to start trading options. In order to trade options it is necessary to sign a special option agreement with a bank or a broker. This is not necessary for warrants. Warrants are also more flexible, since they allow an investor to trade in small amounts. A single option contract entitles its holder to buy 100 shares. Most warrants that are traded have a warrant-ratio that is lower than 1. For example, one warrant "Ahold", mentioned in Section 3.2, entitles its holder to buy one-tenth of a share. This means that warrants make it easier to trade in small amounts. Further, a warrant investor has more flexibility. For example, it is possible for her to buy rights to acquire 150 shares. This is not possible with options. We test whether this flexibility difference affects the overpricing. The hypothesis is that more flexibility, i.e. a lower warrant-ratio, is associated with higher overpricing. In the regressions in Table 4 we find that expected negative relationship between overpricing and the warrant-ratio.

\subsection{Secondary market for options and warrants}

A possible consideration in buying options or warrants is the quality of the secondary market. In Section 2 we have mentioned the paper by Bartram and Fehle (2004), who find that warrant ask prices and bid prices are respectively $4.7 \%$ and $9.9 \%$ higher than option ask and bid prices. They attribute this to the smaller bid-ask spread in warrant markets which makes it easier to sell warrants in the secondary market. Warrant issuers in the Dutch market also promise to 
maintain a secondary market for their own warrants. They also quote bid and ask prices for these warrants. Unfortunately, there are no publicly available records of these bid and ask prices, which makes it impossible to compare them with those of the options market. However, it is highly unlikely that the bid-ask spreads in Dutch warrant markets are better than those in options markets. First of all, the Dutch market for long-term options is very liquid. This market started in 1986, as a reaction on the issue of FALCONS Royal Dutch by Robeco, and has been a big success every since. The secondary market for call warrants is much less liquid, and investors mostly depend on the issuing bank to buy back their warrants ${ }^{27}$.

In order to illustrate this finding, we calculated for the period of the first 10 trading days of the call warrants issued on the stock ABN Amro, the number of trading days of long-term call options on ABN Amro with the same exercise price but a longer maturity. In total we have 5 call warrants on ABN Amro with corresponding call options with a longer maturity but similar exercise price. In the period of the first 10 trading days of the call warrants, the average number of trading days of the call options is 42.6. This indicates that the market for call options is much more liquid than the market for call warrants. This makes it highly unlikely that the secondary market characteristics are responsible for the overpricing of the call warrants; it rather looks like the secondary market is worse for call warrants.

\subsection{No possibility for arbitrage}

Even though the warrants are overpriced, it is not possible for investors to directly profit from this. The reason is that it is not possible to write the warrants and/or go short in them. Therefore, direct arbitrage is not possible. In this sense the case for call warrants and call options is much like the case described by Lamont and Thaler (2003). They study equity carve-outs in the US technology stocks. They find a number of cases in which holders of a share of company A are expected to receive $\mathrm{x}$ shares of company B. Due to short sale constraints this mispricing is not eliminated through arbitrage. Lamont and Thaler (2003) argue that the lack of arbitrage possibilities means that the market is still efficient. However, they argue: "Still, this is market efficiency with very wrong prices".

\subsection{Smaller standard deviation of warrant prices because of bank intervention}

Another factor that may explain part of the overpricing of the warrants is the possibility that warrant prices may be more stable, because of the possibility of 
intervention by the issuing banks. If issuing banks would intervene, we would see a lower standard deviation of warrant prices compared to option prices. In order to scrutinize this explanation we study the first 100 days after the introduction date for both warrants and options. During this period we determine all the options that are used in order to price a warrant. All these option and warrant prices are normalized to the first price of the options and the warrants. The next step is to take the standard deviation of these normalized series. This gives a maximum of 111 standard deviations of the options and the warrants. The final step is to calculate the average of these series. This leads to the following results for the warrants and the options:

- warrant: 0.48

- $\quad$ option with lower exercise price and shorter maturity: 0.33

- $\quad$ option with higher exercise price and shorter maturity: 0.34

- $\quad$ option with lower exercise price and longer maturity: 0.25

- $\quad$ option with higher exercise price and longer maturity: 0.25

These results show either that banks hardly intervene, or that, even if they intervene, the prices of warrants are not more stable than those of options. Therefore this possible explanation is not likely to play an important role in the explanation of the overpricing.

\section{Discussion}

The analysis of the institutional differences in the previous section has not led to a satisfactory explanation of the overpricing of the warrants compared to almost identical call options. For this reason we have searched the financial press and the practitioners' literature for explanations. On top of this we have also held interviews with a selected number of practitioners, some of whom are employed with warrant issuing banks and some who work for other banks.

Both the practitioners and the financial press indicate that call warrants are strongly overvalued compared to call options ${ }^{28}$. These sources also indicate that this overpricing cannot be explained from the institutional factors discussed before. With regard to the secondary market it is confirmed that the long-term call options, which are traded on the options exchange in Amsterdam, are more liquid than the bank-issued call warrants. Even warrant-issuing banks have to admit that the bid-ask spreads in the secondary market are smaller for longterm call options than for call warrants. We have also asked the practitioners why there are not more banks active in the market for call warrants. In general, banks indicate that, even though the profits in the warrant market are substantial, it is also costly for banks to engage in issuing call warrants. It is 
particularly expensive to maintain a secondary market for call warrants. Finally, the practitioners confirm the idea that warrants are almost exclusively bought by individual investors ${ }^{29}$.

The possible explanation that emerges from our talks to practitioners and our search in the practitioners' literature is a combination of financial marketing and the framing effect that was introduced by Tversky and Kahneman (1986). Shefrin and Statman (1993) were the first to present this combination of arguments. They argue that, because of a framing effect, investors are not indifferent to the framing of cash flows. According to their paper the success of covered calls can be attributed to the ability of financial institutions to frame the cash flows of covered calls in such a way that they are appealing to different types of investors. The case that is presented in the underlying paper goes one step further. Call warrants and call options not only give the same cash flows, they are almost identical financial instruments. The most important difference between these financial instruments is their name. Cooper et al. (2001) documented earlier that a different name might lead to a different price. In the period before the bursting of the Internet bubble, they find a strongly significant positive stock price reaction to the announcement of corporate name changes to Internet-related dotcom names.

In our research we find that almost identical financial instruments are traded at different prices. The reason for this is most likely that private investors perceive warrants being different from options. For example, the financial newspaper Het Financieele Dagblad of March 16, 2001 writes (translated): "New this year is the large attention for warrants (..). This product, a kind of option, has the advantage that the risk is limited to the original investment. With options, investors have the possibility to engage in the obligation to buy or to sell, which gives an unlimited risk. With this as a given, banks hope to convince investors who do not want to participate on the "dangerous" options exchange". Sem van Berkel, an important trader on Euronext Amsterdam, in the magazine for the options exchange, Rokin 5, already made a similar statement in 1995. Van Berkel wrote (translated): "Warrants go better with the smart set than options. You can explain as often as you like that options are used to hedge risks, but you still often hear that clients have heard or read something about them that they don't like. It is different with warrants. Apparently it sounds less spooky". The issuing banks also actively try to establish a different image for call warrants compared to call options. In the Dutch financial newspaper, Het Financieele Dagblad, of March 18, 2000, a manager of one of the warrant issuing banks argues: "Warrants are for investors who find stocks too boring and options too wild and complicated". In this context it also has to be remarked that the issuing banks actively advertise investing in warrants. According to Het Financieele 
Dagblad of January 24, 2002, Euronext Amsterdam was also going to start a marketing campaign for investing in warrants. This was probably also caused by the fact that the exchange generates revenues from warrant trading ${ }^{30}$. Since there is hardly any advertising for options, the large popularity of warrants may also partly be explained by the active marketing of this financial product. Hirshleifer (2001) argues that person-to-person and media contagion of ideas is important. He argues that people tend to conform to the judgments and behaviors of others. At least two of the large banks that are active in the Dutch warrant market are very active in organizing seminars. They both organize their own seminars and they give lectures at investment clubs and at the major exchange "Geldzaken" ("Money affairs") that is held annually in the Netherlands. Such places are excellent sources for the contagion of ideas. We consider the combination of financial marketing and the framing by financial institutions to be the most probable explanation for the overpricing of call warrants in relation to call options. The issuing parties on the warrant market apparently have managed to create an image for call warrants that is different from the image of call options. After the first group of individual investors adopted this new instrument, it most likely spread to other individual investors, thereby creating a niche for call warrants as a unique financial instrument.

\section{Summary and conclusions}

Since 1998 the European capital markets have witnessed a large growth in the number of issues of call warrants. These call warrants are issued by a small number of large investment banks. We study the pricing of call warrants in the Dutch capital market. The reason to choose the Dutch market is that the options exchange in Amsterdam also features the trading of long-term call options. This allows us to price the call warrants contingent on the pricing of these call options. We first find a number of cases in which call options with the same exercise price, but with a longer maturity, are priced lower than call warrants written on the same stock. This picture is confirmed when we use implied standard deviations from call options in order to price call warrants. In this analysis we find that on the first five trading days, more than $99 \%$ of the warrants are strongly overvalued. Only a small part of the overpricing can be attributed to rational factors. For example, we find that the transaction costs are lower for call warrants that are relatively cheap compared to other call warrants with the same warrant ratio. However, we also find that this argument only applies to a small part of our sample. Besides that, even in the most extreme cases, the transaction cost difference can only explain an overpricing of $6-7 \%$, while the 
average overpricing is $25-30 \%$. The lack of arbitrage possibilities explains that the overpricing cannot be arbitraged away. However, this still leaves us with the question why investors are willing to pay more for call warrants than for almost identical call options. We suggest that the answer lies in a combination of financial marketing and framing. Apparently, the different way in which the issuing institutions have framed call warrants compared to call options has led to a different image for call warrants. This image may be responsible for the overpricing of call warrants in relation to call options. 


\section{Notes}

${ }^{1}$ See, e.g., Chen et al. (1992), and Wei (1992).

${ }^{2}$ See De Roon and Veld (1996).

${ }^{3}$ Source: the Dutch financial newspaper Het Financieele Dagblad of January 24, 2002.

${ }^{4}$ Euronext Brussels, Amsterdam, and Paris are the respective stock exchanges of Brussels, Amsterdam, and Paris that merged into Euronext.

${ }^{5}$ Bartram and Fehle (2004) argue that regulatory differences could be one of the reasons why bank-issued option markets are virtually non-existent in the United States.

${ }^{6}$ See, e.g. Galai (1977).

${ }^{7}$ The reason for this is that the exchange does not allow short positions in call warrants.

${ }^{8}$ FALCONS is an abbreviation of "Fixed Term Agreements for Long Term Call Options on Existing Securities".

${ }^{9}$ EAGLES is an abbreviation of "Euro-issued American-style Geared Letters Exchangeable for Shares".

${ }^{10}$ See Duffhues and Veld (1997) for an overview.

${ }^{11}$ This rule was first developed by Merton (1973) and can be found in any option pricing textbook, see e.g. Hull (2006).

${ }^{12}$ See e.g. Shastri and Sirodom (1995), Lauterbach and Schultz (1990), and Hauser and Lauterbach $(1996,1997)$. A complete overview of empirical research on warrant pricing can be found in Veld (2003).

${ }^{13}$ An important difference between traditional warrants and call warrants is that the exercise of a traditional warrant leads to the creation of new shares. Research of Schulz and Trautmann (1994) has shown that this effect can be ignored when pricing traditional warrants.

${ }^{14}$ See e.g. Hull (2006, page 296) for a justification of this estimate of the risk-free interest rate. A number of other option pricing studies use the same estimate, see e.g. Roberts et al. (2002).

${ }^{15}$ In reality dividend payments show a growing pattern. However, it is difficult to derive an objective growth rate for the dividend payment. We have experimented with several growth rates and we find that our results are fairly robust if we use a growth rate instead of a constant dividend payment. These results are on request available from the authors.

${ }^{16}$ This so-called smile effect has been studied extensively. See e.g. Pena et al. (2001) for a study on Spanish index options and Navatte and Villa (2000) and Perignon and Villa (2002) for studies on French index options.

${ }^{17}$ The sub-sample includes the warrants for which, on at least one of the five trading days, at least four options are available.

${ }^{18}$ The significance of the medians is tested using the Binomial sign test.

${ }^{19}$ Results for the model of Black and Scholes and the Binomial model on the level of the underlying stocks, like the ones presented for the Square Root model, are on request available from the authors.

${ }^{20}$ Detailed results are, on request, available from the authors.

${ }^{21}$ See Ritter (2003) for an overview of this literature.

${ }^{22}$ Reverse convertible bonds are bonds that can be exchanged into shares of common stock at the option of the issuer. In fact, they are bonds with written put options. Discount certificates are securities in which the holder acquires a bundle of shares at a "discount" compared to the current market price. At the maturity date, these shares are delivered to the holder if the total value of the shares does not exceed a pre-specified maximum amount. Otherwise, the certificate pays this in amount in cash.

${ }^{23}$ Detailed results for the Black and Scholes model and the Binomial models are, on request, available from the authors. 
${ }^{24}$ We have also made calculations for all individual banks and/or brokers. These results are, on request, available from the authors.

${ }^{25}$ These results are available on request from the authors.

${ }^{26}$ The Internet company Belegger.nl does not give information on warrant orders smaller than 1,000 Euros. It may be possible that the transaction cost differences are larger for such orders. However, it will still not explain the full price difference between call warrants and call options.

${ }^{27}$ Private conversation with one of the warrant-issuing banks revealed that most of the times the bank is the counter party of the investor in the secondary market. It also revealed that the bid-ask spreads of the issuing banks are worse than those of the options exchange.

${ }^{28}$ See e.g. Het Financieele Dagblad of June 20, 1998: "Beurshausse leidt tot te dure warrants (transl. Bull markets leads to overpriced warrants)" and Het Financieele Dagblad of June 16, 2001: "Warrant belegger moet op kleintjes letten (transl. Warrant investor has to take care of the pences)".

${ }^{29}$ According to a person from one of the warrant issuing banks, individual investors make up far more than $90 \%$ of the market for call warrants.

${ }^{30}$ The exchange collects 1,000 Euro per listed warrant, and 500 Euro for each year that the warrant is listed. Besides that, the exchange collects 5 Eurocents for each price change. Finally, the exchange collects transaction costs from parties that buy warrants. 


\section{Acknowledgement}

This paper was formerly entitled: "Behavioral preferences for individual securities: the case for call warrants and call options". The authors thank Niall Quann and Ellen Hennekens for their excellent research assistance and an anonymous referee, Iwan Brouwer, John Doukas (the editor), Jeroen Kerkhof, Sabine Kröger, Theo Nijman, Eli Prisman, Ranjini Sivakumar, Lorne Switzer, Yulia Veld-Merkoulova, Bas Werker, Conference participants at the European Financial Management Conference in Helsinki (June 2003), the Multinational Finance Society Conference in Montreal (June 2003), the Financial Management Conference in Denver (October 2003), the Conference of the Northern Finance Association in St. Johns (September 2004) and seminar and workshop participants at Tilburg University and York University for helpful comments and suggestions. Finally, Jenke ter Horst acknowledges the financial support of the Department of Finance at Tilburg University and Chris Veld acknowledges the financial support from Simon Fraser University (President's Research Grant). In addition, we thank Betty Chung for her editing assistance.

\section{References}

Bartram, S., and Fehle, F.: "Alternative market structures for derivatives", working paper, University of South Carolina, 2004.

Beckers, S.: "The constant elasticity of variance model and its implications for option pricing", The Journal of Finance, 1980, page 661-673.

Black, F., and Scholes, M.: "The pricing of options and corporate liabilities", Journal of Political Economy, 1973, page 637-654.

Brenner, M., and Subrahmanyam, M.G.: "A simple formula to compute the implied standard deviation", Financial Analysts Journal, September/October 1988, page 80-83.

Chan, H.W.H., and Pinder, S.M.: "The value of liquidity: evidence from the derivatives market", Pacific-Basin Finance Journal, 2000, page 483-503.

Chen, K., Sears, R.S., and Shahrokhi, M.: "Pricing Nikkei put warrants: some empirical evidence", Journal of Financial Research, 1992, page 231-251.

Cooper, M.J., Dimitrov, O., and Rau, P.R.: "A Rose.com by any other name", The Journal of Finance, 2001, page 2371-2388.

Cox, J.C., and Ross, S.A.: "The valuation of options for alternative stochastic processes", Journal of Financial Economics, 1976, page 145-166. 
Cox, J.C., Ross, S., and Rubinstein, M.: "Option pricing: a simplified approach", Journal of Financial Economics, 1979, page 229-263.

De Roon, F., and Veld, C.: "An empirical investigation of the factors that determine the pricing of Dutch index warrants", European Financial Management, 1996, page 97-112.

Duffhues, P.J.W., and Veld, C.: "Warrants, met bijzondere aandacht voor 'covered', 'basket'-, en 'index'-warrants (transl. Warrants, with a special emphasis on covered-, basket- and index-warrants)", In: Financiële Instrumenten, deel 1: Financiering, belegging en risicobeheersing, P.J.W. Duffhues and J.G. Groeneveld (eds.), Kluwer Bedrijfsinformatie, Deventer, 1997, page 171-201.

Galai, D.: "Characterization of options", Journal of Banking and Finance, 1977, page 373-385.

Hauser, S., and Lauterbach, B.: "Tests of warrant pricing models: the trading profits perspective", The Journal of Derivatives, Winter 1996, page 71-79.

Hauser, S., and Lauterbach, B.: "The relative performance of five alternative warrant pricing models", Financial Analysts Journal, January/February 1997, page 55-61.

Hirshleifer, D.: "Investor psychology and asset pricing", The Journal of Finance, 2001, page 1533-1597.

Hull, J.: "Options, futures, and other derivatives", Sixth edition, Prentice-Hall, Upper Saddle River, New Jersey, 2006.

Lamont, O., and Thaler, R.H.: "Can the market add and subtract? Mispricing in equity carve-outs", Journal of Political Economy, 2003, page 227-268.

Lauterbach, B., and Schultz, P.: "Pricing warrants: an empirical study of the Black-Scholes model and its alternative", The Journal of Finance, 1990, page 1181-1209.

Merton, R.C.: "Theory of rational option pricing", Bell Journal of Economics and Management Science, 1973, page 141-183.

Navatte, P., and Villa, C.: "The information content of implied volatility, skewness and kurtosis: empirical evidence from long-term CAC 40 options", European Financial Management, 2000, page 41-56.

Pena, I., Rubio, G., and Serna, G.: "Smiles, bid-ask spreads and option pricing", European Financial Management, 2001, page 351-374.

Perignon, C., and Villa, C.: "Extracting information from options markets: smiles, state-price densities and risk aversion", European Financial Management, 2002, page 495-513. 
Ritter, J.R.: "Investment banking and securities issuance", In: Handbook of the Economics of Finance, G. Constantinides, M. Harris, and R. Stulz (eds.), Volume 1, Part 1, Elsevier Inc., 2003, page 255-306.

Roberts, G.S., Vijayraghavan, V., and Aintablian, S.: "Stock index-linked debt and shareholder value: evidence from the Paris Bourse", European Financial Management, 2002, page 339-356.

Schulz, G.U., and Trautmann, S.: "Robustness of option-like warrant valuation", Journal of Banking and Finance, 1994, page 841-859.

Shastri, K., and Sirodom, K.: "An empirical test of the BS and CSR valuation models for warrants listed in Thailand", Pacific-Basin Finance Journal, 1995, page $465-483$.

Shefrin, H., and Statman, M.: "Behavioral aspects of the design and marketing of financial products", Financial Management, Summer 1993, page 123-134.

Tversky, A., and Kahneman, D.: "Rational choice and the framing of decisions", Journal of Business, 1986, page S251-S278.

Veld, C.: "Warrant pricing: a review of empirical research", The European Journal of Finance, 2003, page 61-91.

Veld, C., and Verboven, A.: "An empirical analysis of warrant prices versus long-term call option prices", Journal of Business Finance $\mathcal{E}$ Accounting, 1995, page 1125-1146.

Wei, J.Z.: "Pricing Nikkei put warrants", Journal of Multinational Financial Management, 1992, page 45-75.

Wilkens, S., Erner, C., and Röder, K.: "The pricing of structured products in Germany", The Journal of Derivatives, Fall 2003, page 55-69. 
Figure 1: Comparison of prices.

A comparison of the prices of the call warrants on the first five trading days of Ahold with exercise price $€ 37$ and exercise date August 2, 2002 to the call options Ahold with exercise price $€ 37$ and exercise date October 18, 2002.

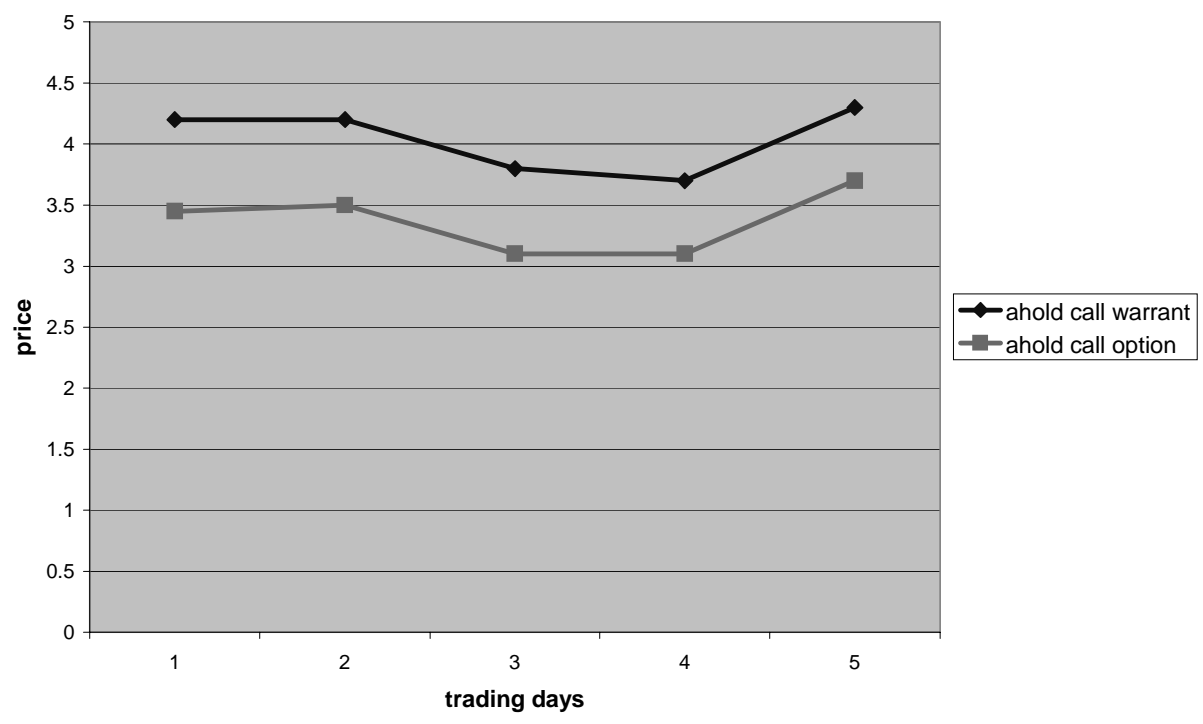


Figure 2: Overpricing of the call warrants during their maturity.

This figure presents the average overpricing of Dutch call warrants issued between January 1, 1999 and December 31, 2001 during their maturity. The call warrants and the underlying stocks are identified from the official newspaper of the Amsterdam Stock Exchange, De Officiële Prijscourant van de Effectenbeurs. The overpricing is defined as the difference between the market price of the warrant and the model price divided by the market price. Model prices are calculated using the Square Root version of the Constant Elasticity of Variance model of Cox and Ross (1976) corrected for continuous dividend payments. The price of the underlying stock, the exercise price, the dividend yield, and the time to maturity of both the options and the warrants are derived from Datastream. The risk-free interest rate is estimated as the average yield on government bonds with a maturity of 2 years (also from Datastream). The volatility of the warrants is defined as the implied volatility of long term call options on the same stocks. The different implied volatilities are weighted in such a way that the options that are closest to the call warrants in terms of exercise price and time to maturity get the highest weight. The graph only includes information on warrants that are actually traded on a certain day. For example, the information on day 50 includes the average overpricing of all call warrants that were traded, i.e. for which there was a positive trading volume, on the 50th day after their issuance. Call warrants are only taken into account if they fulfill all four of the following conditions: (1) The trading volume of the warrant is positive; (2) There are at least two call options on the same underlying stock that have a positive trading volume: one with a longer maturity and one with a shorter maturity; (3) The overpricing is not more than 150\%; (4) The price of the call warrant is at least 0.10 euro.

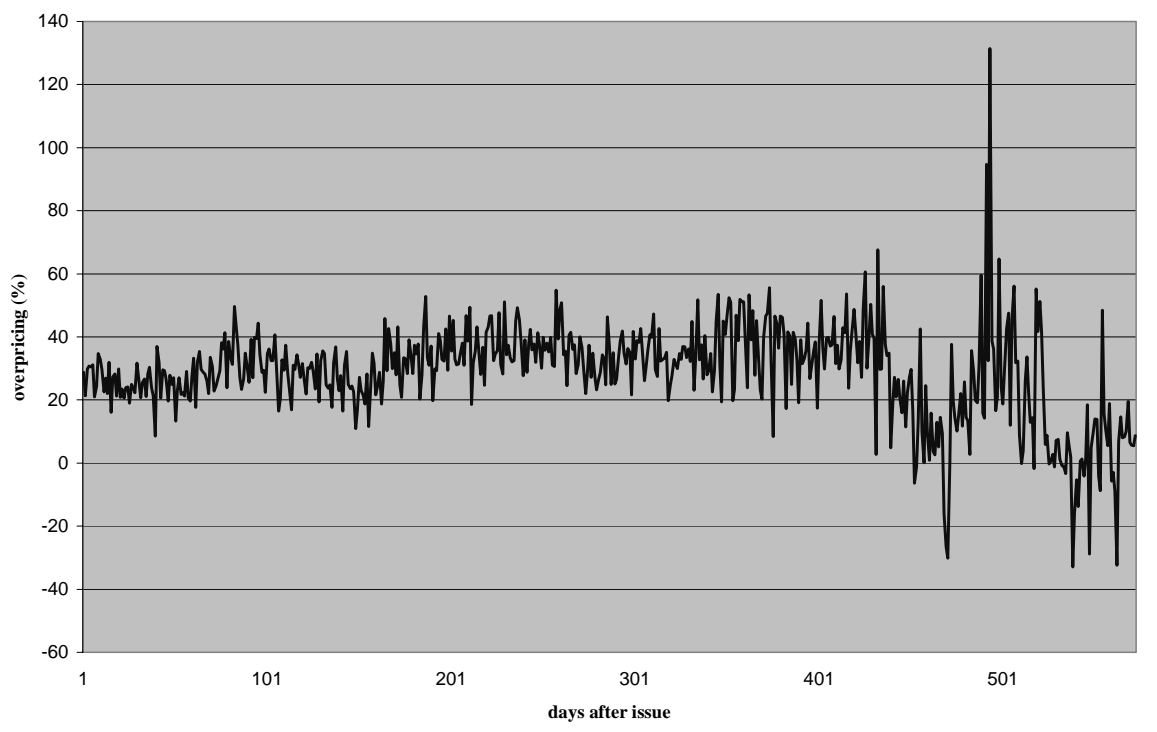


Table 1:

Sample selection.

This table presents the selection of call warrants for our sample. The call warrants and the underlying stocks are identified from the official newspaper of the Amsterdam Stock Exchange, De Officiële Prijscourant van de Effectenbeurs. Column (1) presents the underlying stocks. Column (2) presents all the call warrants that were issued on Euronext Amsterdam in the period from January 1, 1999 to December 31, 2001 on underlying shares on which also long-term call options are available. Column (3) gives the call warrants for which there is no price information available in Datastream. The call warrants that are eliminated because there is conflicting information between different data sources are included in column (4). Call warrants for which we do not have at least five trading days available are presented in column (5). Column (6) gives the call warrants for which it is not possible to find at least five days during the first ten trading days of the call warrant on which not at least both a call option with a longer maturity and a call option with a shorter maturity are being traded. Finally, column (7) gives the final sample.

\begin{tabular}{|c|c|c|c|c|c|c|}
\hline $\begin{array}{c}\text { Underlying } \\
\text { stock }\end{array}$ & $\begin{array}{c}\text { Original } \\
\text { sample }\end{array}$ & $\begin{array}{c}\text { No price } \\
\text { information } \\
\text { in } \\
\text { Datastream }\end{array}$ & $\begin{array}{l}\text { Conflicting } \\
\text { issuance } \\
\text { information }\end{array}$ & $\begin{array}{c}\text { Less than } \\
5 \text { trading } \\
\text { days }\end{array}$ & $\begin{array}{c}\text { Not enough } \\
\text { options } \\
\text { available }\end{array}$ & $\begin{array}{c}\text { Final } \\
\text { sample }\end{array}$ \\
\hline$(1)$ & $(2)$ & (3) & (4) & $(5)$ & $(6)$ & $(7)$ \\
\hline ABN Amro & 18 & 3 & & & 2 & 13 \\
\hline Aegon & 17 & 3 & & & 6 & 8 \\
\hline Ahold & 11 & 1 & & & 1 & 9 \\
\hline Akzo & 12 & 2 & & 2 & & 8 \\
\hline ASML & 25 & 5 & & & 8 & 12 \\
\hline DSM & 5 & 1 & & & 1 & 3 \\
\hline Elsevier & 15 & 1 & & 2 & 1 & 11 \\
\hline Fortis & 13 & 2 & 3 & 5 & 3 & 0 \\
\hline Getronics & 23 & 2 & & 6 & 7 & 8 \\
\hline Heineken & 8 & & & 3 & 5 & 0 \\
\hline ING & 22 & 4 & 2 & 1 & 5 & 10 \\
\hline $\mathrm{KPN}$ & 26 & & & & 22 & 4 \\
\hline Numico & 13 & 2 & & 1 & 8 & 2 \\
\hline Philips & 24 & 5 & & 1 & 9 & 9 \\
\hline Royal Dutch & 13 & 2 & & 1 & 2 & 8 \\
\hline TNT Post & 4 & & & 1 & 3 & 0 \\
\hline Unilever & 5 & & & & & 5 \\
\hline UPC & 15 & 2 & & 5 & 7 & 1 \\
\hline Wolters Kluwer & 6 & & & & 6 & 0 \\
\hline Total & 275 & 35 & 5 & 28 & 96 & 111 \\
\hline
\end{tabular}


Table 2:

Summary statistics

This table presents the summary statistics of the Dutch call warrants issued between January 1, 1999 and December 31, 2001. Call warrants are only included if they are at least traded during five trading days (these are days with a positive trading volume). Trading days are only taken into account if at least one call option with a longer maturity and one call option with a shorter maturity than the warrant are traded. Furthermore, call warrants are only included if during the first 10 trading days at least five days can be found on which the earlier mentioned two options are traded. The call warrants and the underlying stocks are identified from the official newspaper of the Amsterdam Stock Exchange, De Officiele Prijscourant van de Effectenbeurs. The normalized call warrant price represents the price to buy 0.1 share of common stock. The warrant ratio is the number of shares that can be bought with one call warrant. The moneyness is the ratio of the stock price and the exercise price on the first trading date. The price of the underlying stock, the exercise price, the time to maturity, the trading volume of the warrants, the warrant price and the warrant ratio are derived from Datastream. Issuer A refers to the only Dutch issuing bank (ABN Amro). Issuers B, C, and D refer to the foreign issuers. The information on the full sample is presented in Panel A. In Panel B information is presented on the call warrants that are priced using four call options.

\begin{tabular}{lccccr}
\hline Panel A : full sample & \multicolumn{5}{c}{ Issuer } \\
& A & B & C & D & Total \\
\hline Number of warrants & 26 & 32 & 41 & 12 & 111 \\
Avg. warrant price (norm) & 0.55 & 0.53 & 0.53 & 0.69 & 0.55 \\
Med. warrant price (norm) & 0.51 & 0.44 & 0.4 & 0.68 & 0.47 \\
Avg. maturity & 1.41 & 1.68 & 2.02 & 1.33 & 1.71 \\
Med. Maturity & 1.48 & 1.78 & 1.65 & 1.41 & 1.58 \\
Avg. warrant ratio & 0.09 & 0.11 & 0.12 & 0.37 & 0.13 \\
Med. warrant ratio & 0.1 & 0.1 & 0.1 & 0.2 & 0.1 \\
Avg. trading volume & 6516 & 5966 & 9717 & 6314 & 7518 \\
Med. trading volume & 4000 & 4179 & 5280 & 2883 & 4000 \\
Avg. moneyness & 0.9 & 0.87 & 0.8 & 0.89 & 0.85 \\
\hline Panel B : valuation based on 4 options & & Issuer & & \\
& $\mathrm{A}$ & $\mathrm{B}$ & $\mathrm{C}$ & $\mathrm{D}$ & Total \\
\hline Number of warrants & 13 & 19 & 21 & 6 & 59 \\
Avg. warrant price (norm) & 0.46 & 0.55 & 0.65 & 0.87 & 0.6 \\
Med. warrant price (norm) & 0.36 & 0.45 & 0.65 & 0.76 & 0.53 \\
Avg. maturity & 1.4 & 1.7 & 1.95 & 1.25 & 1.67 \\
Med. Maturity & 1.39 & 1.84 & 1.65 & 1.38 & 1.6 \\
Avg. warrant ratio & 0.09 & 0.11 & 0.09 & 0.27 & 0.12 \\
Med. warrant ratio & 0.1 & 0.1 & 0.1 & 0.2 & 0.1 \\
Avg. trading volume & 11133 & 5044 & 6654 & 6638 & 7121 \\
Med. trading volume & 7857 & 4160 & 3920 & 2767 & 4160 \\
Avg. moneyness & 0.89 & 0.87 & 0.85 & 0.97 & 0.88
\end{tabular}


Table 3:

Overpricing of the Dutch call warrants for the Square Root model.

This table presents the overpricing of the Dutch call warrants issued between January 1, 1999 and December 31, 2001. The overpricing is calculated as the average overpricing over the first five trading days of the warrants. Trading days are only taken into account if at least one call option with a longer maturity and one call option with a shorter maturity than the warrant are traded. Warrants are only included if during the first 10 trading days at least five days can be found on which the earlier mentioned two options are traded. The call warrants and the underlying stocks are identified from the official newspaper of the Amsterdam Stock Exchange, De Officiële Prijscourant van de Effectenbeurs. The overpricing is defined as the difference between the market price of the warrant and the model price divided by the market price. Model prices are calculated using the Square Root version of the Constant Elasticity of Variance model of Cox and Ross (1976) corrected for continuous dividend payments. The price of the underlying stock, the exercise price, the dividend yield, and the time to maturity of both the options and the warrants are derived from Datastream. The risk-free interest rate is estimated as the average yield on government bonds with a maturity of 2 years (also from Datastream). The volatility of the warrants is defined as the implied volatility of long term call options on the same stocks. The different implied volatilities are weighted in such a way that the options that are closest to the call warrants in terms of exercise price and time to maturity get the highest weight. The information on the full sample is presented in Panel A. In Panel B information is presented on the call warrants that are priced using four call options. The significance of the averages is tested using a t-statistic. The significance of the medians is tested using the Binomial sign test. ${ }^{* * *}=$ significant at the $1 \%$-level; $* *=$ significant at the $5 \%$-level; ${ }^{*}=$ significant at the $10 \%$-level.

\begin{tabular}{llllllll}
\hline \multicolumn{3}{l}{ Panel A : full sample } & & & & & \\
Stock & war. & Average & St.dev. & Min. & Max. & Med. & pos. \\
\hline ABN Amro & 13 & $38.76^{* * *}$ & 32.19 & 3.27 & 117.02 & $28.97^{* * *}$ & 13 \\
Aegon & 8 & $35.75^{* * *}$ & 16.4 & 19.13 & 65.06 & $27.56^{* * *}$ & 8 \\
Ahold & 9 & $44.88^{* * *}$ & 44.31 & 8.84 & 152.73 & $31.07^{* * *}$ & 9 \\
Akzo & 8 & $38.08^{* * *}$ & 29.34 & 3.28 & 93.84 & $35.29 * * *$ & 8 \\
ASML & 12 & $27.58^{* * *}$ & 16.95 & 8.45 & 71.15 & $23.93^{* * *}$ & 12 \\
DSM & 3 & $12.87^{*}$ & 12.05 & -0.57 & 22.71 & 16.47 & 2 \\
Elsevier & 11 & $45.16^{* * *}$ & 42.17 & 5.02 & 157.5 & $33.94^{* * *}$ & 11 \\
Getronics & 8 & $41.50^{* * *}$ & 38.93 & 17.81 & 134.17 & $26.60^{* * *}$ & 8 \\
ING & 10 & $30.80^{* * *}$ & 14.79 & 10.09 & 51.74 & $30.81^{* * *}$ & 10 \\
KPN & 4 & $35.17^{* * *}$ & 22.92 & 13.06 & 61.03 & 33.29 & 4 \\
Numico & 2 & $98.26^{* *}$ & 68.75 & 49.65 & 146.87 & 98.26 & 2 \\
Philips & 9 & $37.83^{* * *}$ & 19.49 & 15.84 & 71.35 & $39.79^{* * *}$ & 9 \\
Royal Dutch & 8 & $36.26^{* * *}$ & 34.46 & 6.04 & 114.61 & $28.55^{* * *}$ & 8 \\
Unilever & 5 & $30.19^{* * *}$ & 16.49 & 6.51 & 46.61 & $34.77^{* *}$ & 5 \\
UPC & 1 & 20.59 & & 20.59 & 20.59 & 20.59 & 1 \\
\hline Total & 111 & $38.25^{* * *}$ & 4.84 & -0.57 & 157.5 & $29.65^{* * *}$ & 110
\end{tabular}




\begin{tabular}{|c|c|c|c|c|c|c|c|}
\hline \multicolumn{8}{|c|}{ Panel B : valuation based on 4 options } \\
\hline Stock & war. & Average & St.dev. & Min. & Max. & Med. & pos. \\
\hline ABN Amro & 9 & $24.30^{* * *}$ & 10.5 & 3.27 & 35.78 & $26.41 * * *$ & 9 \\
\hline Aegon & 6 & $36.65^{* * *}$ & 17.17 & 24.2 & 65.06 & $27.56^{* *}$ & 6 \\
\hline $\begin{array}{l}\text { Ahold } \\
\text { Akzo }\end{array}$ & 3 & $18.65^{* * *}$ & 12.32 & 8.84 & 32.47 & 14.65 & 3 \\
\hline $\begin{array}{l}\text { ASML } \\
\text { DSM }\end{array}$ & 11 & $28.44^{* * *}$ & 17.5 & 8.45 & 71.16 & $27.55^{* * *}$ & 11 \\
\hline Elsevier & 3 & $26.52^{* * *}$ & 9.38 & 15.98 & 33.94 & 29.41 & 3 \\
\hline Getronics & 5 & $50.38 * *$ & 47.95 & 18.67 & 134.17 & $29.61 * *$ & 5 \\
\hline ING & 5 & $26.15^{* * *}$ & 16.47 & 10.09 & 51.74 & $20.12^{* *}$ & 5 \\
\hline $\mathrm{KPN}$ & 4 & $35.17^{* * *}$ & 22.92 & 13.06 & 61.03 & 33.29 & 4 \\
\hline Numico & & & & & & & \\
\hline Philips & 5 & $33.50^{* * *}$ & 12.77 & 16.83 & 47.36 & $39.79 * *$ & 5 \\
\hline Royal Dutch & 2 & $28.55^{* * *}$ & 4.89 & 25.1 & 32.01 & 28.55 & 2 \\
\hline Unilever & 5 & $30.19^{* * *}$ & 16.49 & 6.51 & 46.61 & $34.77^{* *}$ & 5 \\
\hline UPC & 1 & 20.59 & & 20.59 & 20.59 & 20.59 & 1 \\
\hline Total & 59 & $29.92^{* * *}$ & 2.43 & 3.27 & 134.17 & $27.55^{* * *}$ & 59 \\
\hline
\end{tabular}


Table 4:

Regression results.

This table presents the regression analysis of the overpricing of the Dutch call warrants issued between January 1, 1999 and December 31, 2001. The overpricing is calculated as the average overpricing over the first five trading days of the warrants. Trading days are only taken into account if at least one call option with a longer maturity and one call option with a shorter maturity than the warrant are traded. Warrants are only included if, during the first 10 trading days, at least five days can be found on which the earlier mentioned two options are traded. The call warrants and the underlying stocks are identified from the official newspaper of the Amsterdam Stock Exchange, De Officiële Prijscourant van de Effectenbeurs. The overpricing is defined as the difference between the market price of the warrant and the model price divided by the market price. Model prices in Panels A and B are calculated using the Square Root version of the Constant Elasticity of Variance model of Cox and Ross (1976), corrected for continuous dividend payments. The price of the underlying stock, the exercise price, the dividend yield, and the time to maturity of both the options and the warrants are derived from Datastream. The risk-free interest rate is estimated as the average yield on government bonds with a maturity of 2 years (also from Datastream). The volatility of the warrants is defined as the implied volatility of long term call options on the same stocks. The different implied volatilities are weighted in such a way that the options that are closest to the call warrants in terms of exercise price and time to maturity get the highest weight. The normalized call warrant price represents the price to buy 0.1 share of common stock. The warrant ratio is the number of shares that can be bought with one call warrant. The moneyness (M.ness) is the ratio of the stock price and the exercise price on the first trading date. The warrant-ratio and the trading volume of the warrants are also derived from Datastream. Issuer A refers to the only Dutch issuing bank (ABN Amro). Issuers B, C and D refer to the foreign issuers. The information on the full sample is presented in Panel A. In Panels B information is presented on the call warrants that are priced using four call options. Heteroskedasticity-adjusted standard errors (White) are reported between square brackets. ${ }^{* * *}=$ significant at the $1 \%$-level; ${ }^{* *}=$ significant at the $5 \%$-level; ${ }^{*}$ $=$ significant at the $10 \%$-level. 


\begin{tabular}{|c|c|c|c|c|c|c|c|c|c|}
\hline Panel A: & & ependent & riable & \% overpr & $\begin{array}{l}\text { ng (Squar } \\
\mathrm{ps}: 111\end{array}$ & Root $m$ & lel warra & prices) & \\
\hline $\begin{array}{l}\text { Indep. } \\
\text { Var. }\end{array}$ & Interc. & $\begin{array}{c}\text { Price } \\
\text { (norm) }\end{array}$ & $\begin{array}{c}\text { War. } \\
\text { Ratio }\end{array}$ & B & $\begin{array}{l}\text { Issuer } \\
\mathrm{C}\end{array}$ & $\mathrm{D}$ & M.ness & $\operatorname{Ln}(\mathrm{vol})$ & R2 \\
\hline $\begin{array}{l}\text { Coef. } \\
\text { Std. Err. } \\
\text { t-test }\end{array}$ & $\begin{array}{c}0.561 \\
{[0.065]} \\
8.63^{* * *}\end{array}$ & $\begin{array}{c}-0.341 \\
{[0.078]} \\
-4.37^{* * *}\end{array}$ & & & & & & & 0.16 \\
\hline $\begin{array}{l}\text { Coef. } \\
\text { Std. Err. } \\
\text { t-test }\end{array}$ & $\begin{array}{c}0.606 \\
{[0.075]} \\
8.08 * * *\end{array}$ & $\begin{array}{c}-0.362 \\
{[0.083]} \\
-4.36^{* * *}\end{array}$ & $\begin{array}{l}-0.247 \\
{[0.131]} \\
-1.89 *\end{array}$ & & & & & & 0.17 \\
\hline $\begin{array}{l}\text { Coef. } \\
\text { Std. Err. } \\
\text { t-test }\end{array}$ & $\begin{array}{c}0.191 \\
{[0.019]} \\
10.05^{* * *}\end{array}$ & & & $\begin{array}{c}0.102 \\
{[0.031]} \\
3.29 * * *\end{array}$ & $\begin{array}{c}0.376 \\
{[0.064]} \\
5.88 * * *\end{array}$ & $\begin{array}{c}0.134 \\
{[0.057]} \\
2.35^{* *}\end{array}$ & & & 0.26 \\
\hline $\begin{array}{l}\text { Coef. } \\
\text { Std. Err. } \\
\text { t-test }\end{array}$ & $\begin{array}{c}1.481 \\
{[0.196]} \\
7.56^{* * *}\end{array}$ & & & & & & $\begin{array}{c}-1.299 \\
{[0.211]} \\
-6.16^{* * *}\end{array}$ & & 0.42 \\
\hline $\begin{array}{l}\text { Coef. } \\
\text { Std. Err. } \\
\text { t-test }\end{array}$ & $\begin{array}{c}0.143 \\
{[0.040]} \\
3.58 * * *\end{array}$ & & & & & & & $\begin{array}{c}0.034 \\
{[0.008]} \\
4.25^{* * *}\end{array}$ & 0.14 \\
\hline $\begin{array}{l}\text { Coef. } \\
\text { Std. Err. } \\
\text { t-test }\end{array}$ & $\begin{array}{c}0.995 \\
{[0.157]} \\
6.33^{* * *}\end{array}$ & $\begin{array}{l}-0.113 \\
{[0.063]} \\
-1.81^{*}\end{array}$ & $\begin{array}{c}-0.136 \\
{[0.106]} \\
-1.29\end{array}$ & $\begin{array}{l}0.054 \\
{[0.033]} \\
1.64\end{array}$ & $\begin{array}{l}0.279 \\
{[0.043]} \\
6.44^{* * *}\end{array}$ & $\begin{array}{l}0.153 \\
{[0.046]} \\
3.30^{* * *}\end{array}$ & $\begin{array}{c}-0.861 \\
{[0.191]} \\
-4.49 * * *\end{array}$ & $\begin{array}{c}0.009 \\
{[0.005]} \\
1.91^{*}\end{array}$ & 0.56 \\
\hline Panel B: & & pendent & riable & $\%$ overpri & $\begin{array}{l}\text { ng (Squar } \\
\text { bs : } 59\end{array}$ & Root $\mathrm{mc}$ & lel warran & prices) & \\
\hline $\begin{array}{l}\text { Indep. } \\
\text { Var. }\end{array}$ & Interc. & $\begin{array}{l}\text { Price } \\
\text { (norm) }\end{array}$ & $\begin{array}{l}\text { War. } \\
\text { Ratio }\end{array}$ & B & $\begin{array}{c}\text { Issuer } \\
\mathrm{C}\end{array}$ & $\mathrm{D}$ & M.ness & $\operatorname{Ln}(\mathrm{vol})$ & R2 \\
\hline $\begin{array}{l}\text { Coef. } \\
\text { Std. Err. } \\
\text { t-test }\end{array}$ & $\begin{array}{c}0.387 \\
{[0.059]} \\
6.56^{* * *}\end{array}$ & $\begin{array}{c}-0.134 \\
{[0.067]} \\
-2.00^{* *}\end{array}$ & & & & & & & 0.06 \\
\hline $\begin{array}{l}\text { Coef. } \\
\text { Std. Err. } \\
\text { t-test }\end{array}$ & $\begin{array}{c}0.43 \\
{[0.074]} \\
5.81 * * *\end{array}$ & $\begin{array}{c}-0.142 \\
{[0.068]} \\
-2.09 * *\end{array}$ & $\begin{array}{l}-0.334 \\
{[0.198]} \\
-1.69 *\end{array}$ & & & & & & 0.07 \\
\hline $\begin{array}{l}\text { Coef. } \\
\text { Std. Err. } \\
\text { t-test }\end{array}$ & $\begin{array}{c}0.23 \\
{[0.020]} \\
11.50^{* * *}\end{array}$ & & & $\begin{array}{c}0.014 \\
{[0.031]} \\
0.45\end{array}$ & $\begin{array}{c}0.197 \\
{[0.061]} \\
3.23^{* * *}\end{array}$ & $\begin{array}{c}0.02 \\
{[0.048]} \\
0.42\end{array}$ & & & 0.21 \\
\hline $\begin{array}{l}\text { Coef. } \\
\text { Std. Err } \\
\text { t-test }\end{array}$ & $\begin{array}{c}0.965 \\
{[0.286]} \\
3.37^{* * *}\end{array}$ & & & & & & $\begin{array}{c}-0.75 \\
{[0.309]} \\
-2.43^{* *}\end{array}$ & & 0.27 \\
\hline $\begin{array}{l}\text { Coef. } \\
\text { Std. Err } \\
\text { t-test }\end{array}$ & $\begin{array}{c}0.206 \\
{[0.055]} \\
3.75^{* * *}\end{array}$ & & & & & & & $\begin{array}{c}0.014 \\
{[0.009]} \\
1.56\end{array}$ & 0.05 \\
\hline $\begin{array}{l}\text { Coef. } \\
\text { Std. Err } \\
\text { t-test }\end{array}$ & $\begin{array}{c}0.726 \\
{[0.236]} \\
3.07^{*} * *\end{array}$ & $\begin{array}{c}-0.070 \\
{[0.061]} \\
-1.14\end{array}$ & $\begin{array}{c}-0.271 \\
{[0.247]} \\
-1.10\end{array}$ & $\begin{array}{l}0.011 \\
{[0.035]} \\
0.32\end{array}$ & $\begin{array}{l}0.199 \\
{[0.047]} \\
4.25^{* * *}\end{array}$ & $\begin{array}{l}0.132 \\
{[0.148]} \\
1.64\end{array}$ & $\begin{array}{c}-0.566 \\
{[0.262]} \\
-2.16 * *\end{array}$ & $\begin{array}{c}0.009 \\
{[0.007]} \\
1.30\end{array}$ & 0.47 \\
\hline
\end{tabular}


Table 5:

Transaction costs for call warrants and call options.

Transaction costs (in Euro) for call warrants and call options are presented for four different scenarios for the warrant price. In all scenarios it is assumed that an investor purchases call warrants for a total value of 1,000 Euro. The warrant price scenarios are included in column (1). The average transaction costs of warrants based on eight different banks and brokers are included in columns (2) and (3). Each warrant entitles her to buy 0.1 shares of common stock. It is also assumed that the investor buys call options that entitle her to buy the same number of shares. In the first scenario (row 1) the warrant price is 0.1 Euro. Therefore, the investor buys 10,000 warrants. A similar position can be acquired by buying 10 option contracts (each allowing her to buy 100 shares). The option transaction costs of the first scenario are included in columns (4) and (5). In the second scenario (row 2) the warrant price is 0.2 Euro, allowing the investor to buy 5,000 warrants. The transaction costs are the same as in the first scenario and are included in columns (2) and (3). An equivalent position can be acquired by buying 5 option contracts. The transaction costs for the position are included in columns (4) and (5) of the second scenario. In the third scenario (row 3 ) the warrant price is 0.5 Euro. In this case an equivalent position can be taken by buying 2 option contracts. Finally, in the fourth scenario (row 4) the warrant price is 1 Euro. Here an equivalent position can be acquired by buying 1 option contract. In the third and the fourth scenario the transaction costs for the option contracts are included in columns (4) and (5). Columns (6) and (7) in each scenario present the difference in transaction costs expressed in the price per warrant. Columns (8) and (9) give this difference as a percentage of the warrant price. The transaction costs are the averages of the transaction costs of eight different banks and brokers, which are derived from the Internet company "Belegger.nl" on February 19, 2002. P = phone trade. $\mathrm{I}=$ Internet trade.

\begin{tabular}{lcccccccc}
\hline $\begin{array}{l}\text { Warrant } \\
\text { price }\end{array}$ & \multicolumn{2}{c}{$\begin{array}{c}\text { Transaction } \\
\text { costs }\end{array}$} & \multicolumn{2}{c}{$\begin{array}{c}\text { Transaction } \\
\text { costs }\end{array}$} & \multicolumn{2}{c}{$\begin{array}{c}\text { Difference } \\
\text { per warrant }\end{array}$} & \multicolumn{2}{c}{$\begin{array}{c}\text { Difference } \\
\text { per warrant } \\
(1)\end{array}$} \\
warrants & \multicolumn{2}{c}{ options } & \multicolumn{2}{c}{ (in Euros) } & \multicolumn{2}{c}{ (percentage) } \\
$(2)$ & $(3)$ & $(4)$ & $(5)$ & $(6)$ & $(7)$ & $(8)$ & $(9)$ \\
\hline 0.1 & 15.6 & 12 & 52.6 & 42.8 & 0.0074 & 0.0062 & 7.4 & 6.2 \\
0.2 & 15.6 & 12 & 27.9 & 22.7 & 0.0049 & 0.0043 & 2.5 & 2.1 \\
0.5 & 15.6 & 12 & 15.7 & 13.3 & 0.0001 & 0.0013 & 0.0 & 0.7 \\
1.0 & 15.6 & 12 & 14.3 & 11.8 & -0.0026 & -0.0002 & -0.3 & 0.0
\end{tabular}

